Journal of Patient-Centered

\title{
Measuring Patients' Perceptions of Health Care Encounters: Examining the Factor Structure of the Revised Patient Perception of Patient-Centeredness (PPPC-R) Questionnaire
}

\author{
Bridget L. Ryan \\ Judith Belle Brown \\ Paul F. Tremblay \\ Moira Stewart
}

Follow this and additional works at: https://aah.org/jpcrr

Part of the Health and Medical Administration Commons, Health Services Research Commons, Investigative Techniques Commons, and the Primary Care Commons

\section{Recommended Citation}

Ryan BL, Brown JB, Tremblay PF, Stewart M. Measuring patients' perceptions of health care encounters: examining the factor structure of the revised Patient Perception of Patient-Centeredness (PPPC-R) questionnaire. J Patient Cent Res Rev. 2019;6:192-202. doi: 10.17294/2330-0698.1696

Published quarterly by Midwest-based health system Advocate Aurora Health and indexed in PubMed Central, the Journal of Patient-Centered Research and Reviews (JPCRR) is an open access, peer-reviewed medical journal focused on disseminating scholarly works devoted to improving patient-centered care practices, health outcomes, and the patient experience. 


\title{
Measuring Patients' Perceptions of Health Care Encounters: Examining the Factor Structure of the Revised Patient Perception of Patient-Centeredness (PPPC-R) Questionnaire
}

\author{
Bridget L. Ryan, PhD, Judith Belle Brown, PhD, Paul F. Tremblay, PhD, Moira Stewart, PhD \\ Western University, London, Canada
}

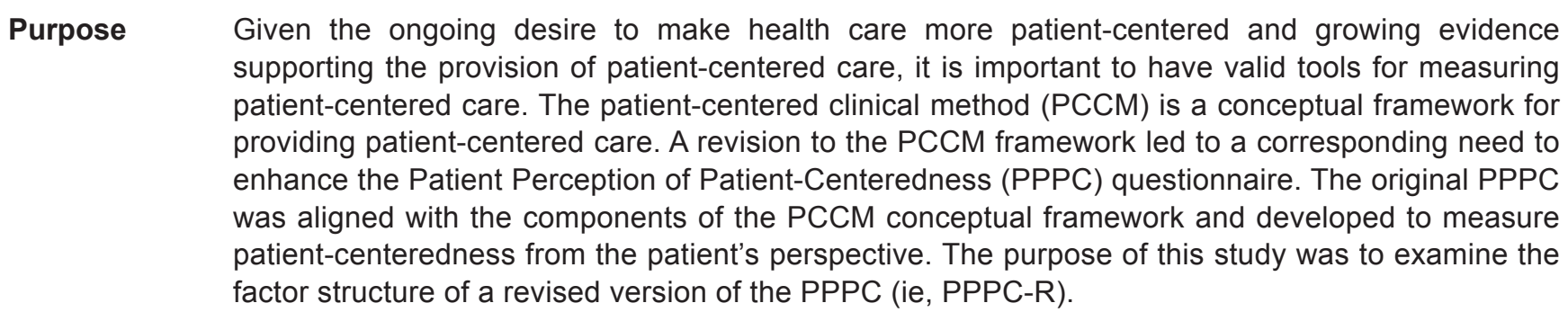

Methods Eleven new items were added to the original 14 items. The modified questionnaire was administered to patients in primary health care teams in Ontario, Canada. The confirmatory factor analysis was conducted on a subset of 381 patients who had seen a family physician.

Results The initial proposed 4-factor model first tested with a confirmatory factor analysis (CFA) did not fit adequately. Exploratory factor analysis was therefore used as a second step to modify the model and to identify weak items. A 3-factor exploratory model with 18 of the original 25 items was converted into a final hypothetical CFA model that had a good fit $\left(X^{2}{ }_{(132)}=176.795, P<0.01\right.$; CFI $=0.991$; RMSEA $=0.030$ ). The third factor contained only 2 items and so is interpreted with caution.

Conclusions The validity of the PPPC-R is supported by some congruence between the conceptual framework (the PCCM) and the statistical analysis (CFA), but there is not a 1:1 correspondence. The components of the PCCM represent conceptually what is important when teaching, researching, and providing patient-centered care, whereas the PPPC-R represents patient-centered care as it is experienced by the patient. (J Patient Cent Res Rev. 2019;6:192-202.)

Keywords patient-centered; surveys; questionnaires; factor analysis; patient-centredness [sic]

I nternationally, researchers and policy makers continue to seek ways to make health care more patient-centered. ${ }^{1-6}$ Patient-centeredness can be thought of as having two principal aspects: a health systems aspect and a patient-clinician relationship aspect. The health system aspect is concerned with

Correspondence: Bridget L. Ryan, PhD,

Western Centre for Public Health and Family Medicine, 1465 Richmond St, Room 2106, London, ON, Canada, N6A 3K7 (bryan@uwo.ca) such processes as transitions from one mode of care to another and with the overall coordination of a patient's care, for example, having the patient's health care information easily accessible to clinicians across the health system. The relationship aspect is concerned with the interactions and ongoing relationship that develops between a patient and his or her clinician. While both aspects are important, this article addresses the measurement of the relationship aspect.

\section{Evidence Supporting Patient-Centered Care} There is a growing evidence base that supports the 
provision of patient-centered care. Little et al found that $75 \%$ of patients endorsed and had expectations of care that addressed the components of the patient-centered clinical method (PCCM). ${ }^{7}$ Patientcentered care has been associated with higher patient satisfaction; ${ }^{8-10}$ better patient adherence, ${ }^{8,11-13}$ better patient health outcomes, such as reduction of concern and discomfort; ${ }^{14}$ better self-reported health; $;^{14,15}$ improved physiological status; ; $8,11,16-19$ and lower costs of care. ${ }^{20,21}$ Also, there may be an argument developing for patient-centeredness as a force for equity. In a study by Jani et al, patient-centered care was associated with positive mental health outcomes for depressed patients, with the effect being found equally in affluent and deprived areas. ${ }^{22}$

\section{The Patient-Centered Clinical Method}

The conceptual framework used in this study is the PCCM, which was developed in the 1980s and originally articulated as 6 interacting components. ${ }^{23}$
Prior to publication of the third edition of PatientCentered Medicine: Transforming the Clinical Method, ${ }^{24}$ the book's authors reviewed the PCCM, reflecting on the current context and research evidence, and made a substantial revision to the method, which culminated in a refined 4-component conceptual framework: 1) exploring health, disease, and the illness experience; 2) understanding the whole person; 3) finding common ground; and 4) enhancing the patientclinician relationship.

Figure 1 presents the 4 components and how they interact. Finding common ground, situated in the center of the clinical method, serves as a linchpin in the patient-clinician interaction. The first 3 components take place primarily within a given encounter. The fourth component speaks to the relationship that evolves and is enhanced across multiple encounters. The PCCM is not about clinician characteristics but rather a clinical method and, therefore, refers to
1: Exploring Health, Disease and the IIIness Experience

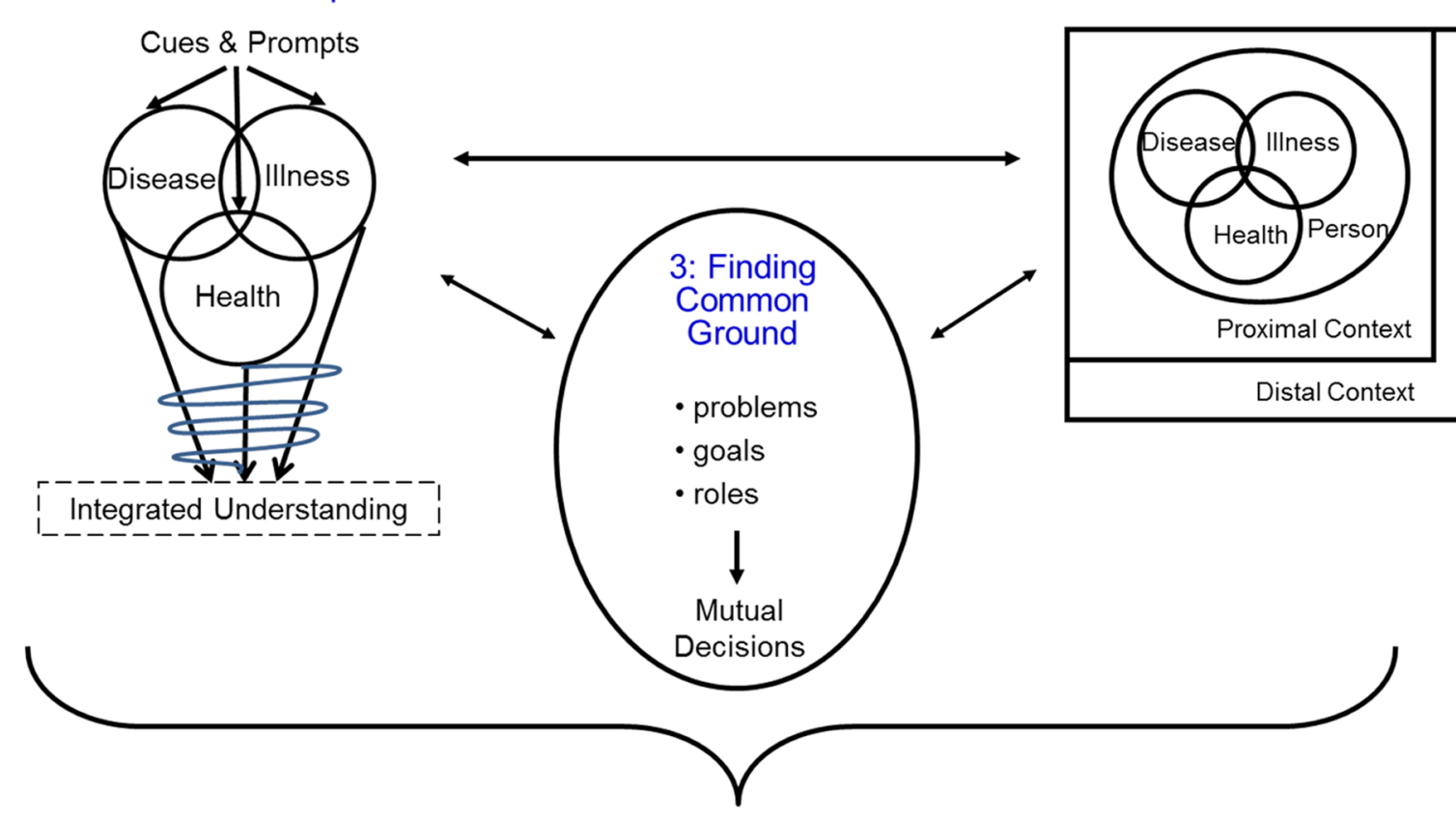

4: Enhancing the patient-clinician relationship
2: Understanding the Whole Person

Figure 1. The 4 interactive components of the patient-centered clinical method. (Figure republished from Stewart $\mathrm{M}$, Brown JB, Weston WW, McWhinney I, McWilliam CL, Freeman TR. Patient-Centered Medicine: Transforming the Clinical Method, Third Edition. London, UK, Radcliffe Publishing, 2014, p. 8, with permission from Taylor \& Francis Group.) 
activities that guide interactions with patients in order to provide patient-centered care.

\section{Development and Use of the Original PPPC Questionnaire}

The Patient Perception of Patient-Centeredness (PPPC) questionnaire was initially created in 1986 and refined in 1990. The intention was to develop a measure that would assess the degree to which the patient believed the clinician was patient-centered, using the PCCM as the conceptual framework for defining patient-centeredness. The original measure had 14 items, which mapped to the first 3 of the original 6 PCCM components: 1) exploring disease and illness; 2) understanding the whole person; and 3) finding common ground. Of the original 6 components, these 3 represent the more interaction-specific components. ${ }^{24}$

The PPPC has been used in studies with family practice populations $^{14,25}$ and with specialized populations such as breast cancer survivors ${ }^{15,26,27}$ and the elderly. ${ }^{28}$ In addition to having been used with real patients, the PPPC has been used with standardized patients. ${ }^{29}$ The internal consistency reliability of the questionnaire, as indicated by Cronbach $\alpha$ values, was found to be high in these studies: $0.71(n=315) ;{ }^{14} 0.91 \quad(n=145$, 12-item), ${ }^{28} 0.90(\mathrm{n}=2907) ;{ }^{29} 0.82(\mathrm{n}=60) ;{ }^{27}$ and 0.83 $(\mathrm{n}=222) .{ }^{25}$ The PPPC showed a modest correlation with an observational measure of patient-centeredness $-\mathrm{r}=0.16, \mathrm{P}=0.01(\mathrm{n}=315)^{14}-$ and it has been related to patient outcomes (ie, better recovery from concern and discomfort, better emotional health) and health care utilization. ${ }^{14,21}$ Since 2001, we have received more than 200 requests to use the PPPC from researchers in Australia, Belgium, Brazil, Canada, Israel, Japan, Nigeria, Russia, Spain, Turkey, United Kingdom, and the United States.

The transition to a 4-component PCCM provided us with an opportunity to review the PPPC questionnaire and reflect on possible modifications. ${ }^{24}$ Even with the new 4-component method, the survey still only mapped to 3 components: exploring health, disease, and the illness experience; understanding the whole person; and finding common ground. We had no items that assessed enhancing the patient-clinician relationship. Also, within the 3 PCCM components that were covered by the 14-item PPPC, some components were better represented than others. Therefore, the objective of this study was to create an expanded version of the PPPC that captured the 4 components of the PCCM and to explore the factor structure of this new version.

\section{METHODS}

\section{Measure}

We created 11 new items, aligned with the theoretical model of the PCCM, to add to the original 14 PPPC items; therefore, all 25 items were in concordance with the 4 components of the PCCM as summarized by Stewart et al (see Box 1.1 of 2014 edition) and further elaborated in each of the component chapters. ${ }^{24}$ The 11 new items were adapted from other questionnaires in the literature. Distribution of the 25 items according to the PCCM components was: 1) exploring health, disease, and the illness experience (4 original items +1 new item); 2) understanding the whole person (1 original item +4 new items); 3 ) finding common ground (9 original items +1 new item); and 4) enhancing the patient-clinician relationship (5 new items). The centrality and complexity of Component 3 - finding common ground - dictated there be more items for this construct.

Items for Component 1 recognize the patient's disease and illness experience, including the patient's feelings and ideas, the impact on the patient's function, and the patient's expectations of the provider. Component 2 items reflect the provider's understanding of and care concerning the patient's personal circumstances and concerns within a proximal (eg, family) and distal (eg, cultural beliefs) context. Items for Component 3 concern mutual discussion and shared understanding reflected by patient and provider together defining the problem, goals, and roles of both the patient and the provider. Lastly, Component 4 items include the attributes of compassion, caring, and trust.

The PPPC is completed by the patient after an encounter with a health care clinician. The questionnaire is self-administered and most often completed in the waiting room before the patient leaves the clinic. Usually a research assistant is present to answer any patient questions. For each item, the patient is asked to "Please circle the response that best represents your opinion." The response categories are on a scale from 1 to 4 , with 1 indicating more and 4 indicating less 
patient-centered experiences. The value labels of each response category vary as appropriate for the question. Scores for the PPPC are calculated by obtaining the mean of all items overall and within subscales.

\section{Participants}

We administered the modified PPPC to patients as part of a study examining team functioning in 20 interdisciplinary primary health care teams in Ontario. Patients were eligible to participate in the study if they were 18 years of age or older, spoke English, and were well enough to be able to understand and complete the survey. Also, they must have seen the same family physician at least once previously and were not visiting for a purely administrative reason such as completing an insurance form. All other reasons for visiting were acceptable.

Patients completed the surveys in the waiting room immediately following their visit to their family physicians. Patients were told through the letter of information that the purpose of this study was to 'examine patients' perceptions of the patientcenteredness of their primary health care and their perception of access to care." The access-to-care questions were not part of this factor analysis. In addition to the patient-centeredness and access questions, patients were asked their sex, age (by category), education, and name of health care provider visited (we included only those visits with family physicians in this analysis).

\section{Analysis Plan}

The proposed 4-factor confirmatory factor analysis (CFA) model was tested using Mplus Version 7.330 with the weighted least squares means and variance (WLSMV) estimator to account for the categoricalordinal nature of the items and the fact that distributions of the item responses were skewed. The "categorical" option was specified to indicate that items were measured on an ordered discrete scale rather than a continuous one. In Mplus, this specification refers to Samejima's graded response model. ${ }^{31,32}$ Also, there are two different strategies in Mplus for accounting for the multilevel structure of the data (ie, patients clustered within 20 practices). One is to conduct a multilevel modeling analysis; the other, which was more appropriate given our objective, is to simply account for the nonindependence of the observations by specifying the "type = complex" procedure along with "cluster" in Mplus.

In Mplus, missing values were estimated based on the available data. When WLSMV is used in Mplus, a pairwise deletion procedure is used. Six cases were excluded by the Mplus procedure for missing data on all items. Additional missing responses ranged from 3 to 35 responses per item. Items with highest missing responses were not unique in any way except that their content addressed roles for treatment and management. It is possible that some participants may have assumed that these items were not applicable to them. Although in most research it is impossible to establish the property of missing completely at random, inspection of missing response patterns suggested no systematic bias in the sense that participants who did not respond to particular items would differ on the concepts that were assessed by the present measure and would not depart substantially from the property of missing at random.

In the event that model modification was required, the decision was made that, as a second step, model modification would be conducted in exploratory factor analysis (EFA) using Mplus and the same WLSMV estimation procedure with a Geomin rotation. Oblique rotation was chosen to obtain a more interpretable structure by specifying a correlated structure given that the underlying hypothesized concepts were not expected to be completely independent. In Mplus, Geomin is a good choice for oblique rotation. We opted for follow-up model investigation using EFA rather than CFA to have more flexibility in inspecting alternative numbers of factors.

\section{RESULTS}

There were 381 patients who had seen a family physician across 20 sites for an average of 19 patients per site. ${ }^{33}$ The majority (70\%) of respondents were female, $64 \%$ were 45 years of age or older, and $71 \%$ had at least some post-secondary education.

The initial proposed 4-factor model first tested with a CFA did not fit adequately; it did not converge to an appropriate solution due to a nonadmissible correlation greater than 1.0 between the first two factors. EFA was 
therefore used as a second step to modify the model and to identify weak items. Given that the 4-factor model did not fit the data well, we tested a 3-factor model without constraining the indicators to particular factors (as would be done in CFA).

The researchers (B.L.R., J.B.B.) reviewed these results and determined that the 3 -factor solution was conceptually sound based on this model having good fit: $\chi_{(228)}^{2}=287.117, \mathrm{P}<0.01$; comparative fit index $(\mathrm{CFI})=0.992$; root mean square error of approximation $($ RMSEA $)=0.026(90 \%$ CI: 0.015-0.035). Regardless of good model fit, several weak items were identified and removed one at a time, repeating the EFA with each reduced set of items. Five items were removed because they had low loadings on all factors and/ or higher loadings on a factor to which they did not belong. Two items were removed because they were each too highly correlated (above 0.90 ) with other items, suggesting that they were redundant.

The final EFA with its 3 modified factors is presented in Table 1; model fit was $\chi_{(102)}^{2}=133.307, \mathrm{P}<0.01$; CFI $=0.994 ; \quad$ RMSEA $=0.029 \quad(90 \% \quad$ CI: $\quad 0.012-$ 0.041). The 3 factors were: F1) Health care process (corresponding to PCCM Components 1 and 3); F2) Context \& relationship (corresponding to PCCM Components 2 and 4); and F3) Roles (corresponding to PCCM Component 3). As shown in Table 1, the factor loadings (ie, pattern coefficients) defining the factors were high, with values ranging from 0.600 to 0.774 , 0.656 to 0.917 , and 0.733 to 0.929 for F1, F2, and F3, respectively. There were no cross loadings greater than 0.374. Correlations among factors were 0.657 for $\mathrm{F} 1$ with F2, 0.430 for F1 with F3, and 0.535 for F2 with F3. These correlations are not too high to suggest lack of discriminant validity among the 3 factors. Table 2 reports the 18-item means, standard deviations, and response patterns, along with the overall Cronbach $\alpha$ value for the 18 items and the Cronbach $\alpha$ for each of the 3 factors.

A 3-factor EFA model with 18 of the original 25 items was converted into a final more restricted hypothetical CFA model with cross-loadings set at zero. It is important to point out here that our intention was not to confirm the model but to evaluate the model fit of this more restrictive model. In other words, we were inspecting how good model fit would be if we had started with this CFA model. Confirmation of this final restrictive model would require cross-validation with a different sample size. Fit of this final model was $\chi_{(132)}^{2}=176.795, \mathrm{P}<0.01 ; \mathrm{CFI}=0.991 ; \mathrm{RMSEA}=0.030$ (90\% CI: $0.017-0.041)$. Figure 2 illustrates this model with the standardized loadings and correlations among the factors. Overall, this model fits very well according to fit indices, with a CFI value above 0.95 and a RMSEA value below 0.05 . The loadings are all high, ranging from 0.63 to 0.96 . Correlations among the factors range from 0.63 to 0.78 and show moderate overlap. Although there are no specific cut-off values for high levels of overlap, correlations greater than \pm 0.85 would be concerning.

Table 3 reports the number of items that loaded on to each factor according to the 4 components of the PCCM conceptual framework. Although the 3 factors in the CFA model are substantially correlated in the range of 0.63 to 0.78 , indices of discriminant validity based on the square root of the average variance extracted ${ }^{34}-$ $0.84,0.84$, and 0.90 for $\mathrm{F} 1, \mathrm{~F} 2$, and F3, respectively - were higher than these factor intercorrelations, supporting the discriminant validity of the factors.

\section{DISCUSSION}

The final CFA elaborated an 18-item 3-factor structure for the revised PPPC (PPPC-R). The overall internal consistency reliability for the 18 -item scale was strong, as was the internal consistency reliability for each factor. To understand the relationship between the PCCM conceptual model and the factor solution, it is helpful to refer to Table 3, which maps PCCM components to the factor solution. The far-left column indicates PCCM components we hypothesized that the CFA would reveal. The top row indicates the factors that were actually revealed by the CFA. We did not find the 4-factor solution that we had hypothesized; therefore, we will discuss each of the 3 factors identified.

Factor 1 consisted of items hypothesized to load onto two separate factors representing PCCM Component 1 (exploring health, disease, and illness experience) and PCCM Component 3 (finding common ground). These two components represent for the patient what happens regarding the actual problem or problems they are presenting to their clinician - What is wrong? 
Table 1. Factor Loadings in Final Exploratory Factor Analysis of the Revised Patient Perception of PatientCenteredness Questionnaire

\begin{tabular}{|c|c|c|c|}
\hline Item Number and Question & $\begin{array}{c}\text { Factor 1: } \\
\text { Health Care } \\
\text { Process }\end{array}$ & $\begin{array}{c}\text { Factor 2: } \\
\text { Context \& } \\
\text { Relationship }\end{array}$ & $\begin{array}{l}\text { Factor 3: } \\
\text { Roles }\end{array}$ \\
\hline 1. To what extent was your main problem(s) discussed today? & 0.741 & -0.064 & 0.001 \\
\hline 2. How well do you think your provider understood you today? & 0.736 & 0.249 & -0.010 \\
\hline 3. How satisfied were you with the discussion of your problem today? & 0.774 & 0.268 & -0.119 \\
\hline 4. To what extent did your provider explain this problem to you? & 0.739 & 0.044 & 0.145 \\
\hline 5. To what extent did you agree with your provider's opinion about the problem? & 0.656 & 0.172 & 0.108 \\
\hline 6. To what extent did your provider ask about your goals for treatment? & 0.600 & 0.021 & 0.337 \\
\hline 7. To what extent did your provider explain treatment? & 0.730 & -0.009 & 0.306 \\
\hline $\begin{array}{l}\text { 8. To what extent did your provider explore how manageable this treatment } \\
\text { would be for you? }\end{array}$ & 0.765 & -0.120 & 0.374 \\
\hline 9. To what extent did you and your provider discuss your respective roles? & -0.003 & 0.013 & 0.929 \\
\hline $\begin{array}{l}\text { 10. To what extent did your provider encourage you to take the role you wanted } \\
\text { in your own care? }\end{array}$ & 0.233 & 0.019 & 0.733 \\
\hline 11. How much would you say that this provider cares about you as a person? & 0.024 & 0.766 & 0.100 \\
\hline 12. To what extent does your provider know about your family life? & -0.047 & 0.656 & 0.096 \\
\hline $\begin{array}{l}\text { 13. How comfortable are you discussing personal problems related to your health } \\
\text { with your provider? }\end{array}$ & -0.018 & 0.820 & -0.114 \\
\hline 14. To what extent does your provider respect your beliefs, values and customs? & -0.013 & 0.873 & -0.149 \\
\hline 15. To what extent does your provider consider your thoughts and feelings? & -0.093 & 0.917 & -0.082 \\
\hline 16. To what extent does your provider show you compassion? & 0.161 & 0.757 & 0.046 \\
\hline 17. To what extent does your provider really listen to you? & 0.222 & 0.726 & 0.014 \\
\hline 18. To what extent do you trust your provider? & 0.052 & 0.850 & 0.028 \\
\hline
\end{tabular}

Note: Factor loadings (ie, pattern coefficients) with Geomin rotation. Correlations among factors are 0.657 for F1 with F2, 0.430 for F1 with F3, and 0.535 for F2 with F3. Correlations and loadings (bolded) used to define factors are statistically significant $(P<0.01)$.

What am I worried about? How is it impacting on my life? What is the diagnosis? and What are we going to do about it? We make the distinction in the PCCM that, within Component 1, the clinician discusses with the patient the reason that brings them to the particular encounter in order to understand their health, disease, and illness experience fully. Component 3 then concerns working with the patient to find common ground concerning the nature of the problem and how the patient and the clinician will manage the problem together. When viewed from the perspective of the patient, it is reasonable that these two discussions will be seen as addressing overall their reason for visiting the clinician. Therefore, F1 combines PCCM Components 1 and 3 into a factor about health care process.

Factor 2 (except for 1 item) consisted of items hypothesized to load onto two separate factors representing PCCM Component 2 (understanding the whole person) and PCCM Component 4 (enhancing relationship). These two components represent for the patient the nature of how they actually interact with their clinician - Do you understand my life? 
Table 2. Descriptive Statistics of PPPC-R Items by Factor (Cronbach $\alpha$ )

\begin{tabular}{|c|c|c|c|c|c|}
\hline \multirow{2}{*}{$\begin{array}{l}\text { PPPC-R Question (18-item Cronbach } 0 \\
\text { Factor 1: Health care process }(\alpha=0.865)\end{array}$} & \multirow[t]{2}{*}{$\mathbf{n}$} & \multirow[t]{2}{*}{ Mean } & \multirow[t]{2}{*}{ SD } & \multicolumn{2}{|c|}{$\begin{array}{l}\text { Response Category and } \\
\text { Proportion }\end{array}$} \\
\hline & & & & & \\
\hline 1. To what extent was your main problem(s) discussed today? & 368 & 1.23 & 0.51 & $\begin{array}{l}1 \text { - Completely } \\
2 \text { - Mostly } \\
3 \text { - A little } \\
4 \text { - Not at all } \\
\end{array}$ & $\begin{array}{l}0.807 \\
0.158 \\
0.033 \\
0.003\end{array}$ \\
\hline 2. How well do you think your provider understood you today? & 372 & 1.09 & 0.32 & $\begin{array}{l}1 \text { - Very well } \\
2-\text { Well } \\
3 \text { - Somewhat } \\
4 \text { - Not at all } \\
\end{array}$ & $\begin{array}{l}0.917 \\
0.075 \\
0.008 \\
0.000 \\
\end{array}$ \\
\hline 3. How satisfied were you with the discussion of your problem? & 371 & 1.20 & 0.45 & $\begin{array}{l}1 \text { - Very satisfied } \\
2 \text { - Satisfied } \\
3 \text { - Somewhat satisfied } \\
4 \text { - Not satisfied } \\
\end{array}$ & $\begin{array}{l}0.811 \\
0.175 \\
0.011 \\
0.003 \\
\end{array}$ \\
\hline 4. To what extent did your provider explain this problem to you? & 366 & 1.21 & 0.48 & $\begin{array}{l}1 \text { - Completely } \\
2-\text { Mostly } \\
3-\text { A little } \\
4-\text { Not at all }\end{array}$ & $\begin{array}{l}0.820 \\
0.148 \\
0.033 \\
0.000\end{array}$ \\
\hline $\begin{array}{l}\text { 5. To what extent did you agree with your provider's opinion about } \\
\text { the problem? }\end{array}$ & 366 & 1.23 & 0.51 & $\begin{array}{l}1-\text { Completely } \\
2 \text { - Mostly } \\
3 \text { - A little } \\
4 \text { - Not at all } \\
\end{array}$ & $\begin{array}{l}0.806 \\
0.169 \\
0.016 \\
0.008 \\
\end{array}$ \\
\hline $\begin{array}{l}\text { 6. To what extent did your provider ask about your goals for } \\
\text { treatment? }\end{array}$ & 355 & 1.45 & 0.71 & $\begin{array}{l}1 \text { - Completely } \\
2 \text { - Mostly } \\
3 \text { - A little } \\
4 \text { - Not at all } \\
\end{array}$ & $\begin{array}{l}0.648 \\
0.279 \\
0.045 \\
0.028 \\
\end{array}$ \\
\hline 7. To what extent did your provider explain treatment? & 355 & 1.27 & 0.55 & \begin{tabular}{|l}
$1-$ Very well \\
$2-$ Well \\
3 - Somewhat \\
4 - Not at all \\
\end{tabular} & $\begin{array}{l}0.777 \\
0.186 \\
0.028 \\
0.008 \\
\end{array}$ \\
\hline $\begin{array}{l}\text { 8. To what extent did your provider explore how manageable this } \\
\text { treatment would be for you? }\end{array}$ & 345 & 1.34 & 0.62 & $\begin{array}{l}1 \text { - Completely } \\
2 \text { - Mostly } \\
3 \text { - A little } \\
4 \text { - Not at all } \\
\end{array}$ & $\begin{array}{l}0.725 \\
0.226 \\
0.035 \\
0.014 \\
\end{array}$ \\
\hline \multicolumn{6}{|l|}{ Factor 2: Context \& relationship ( $\alpha=0.868)$} \\
\hline $\begin{array}{l}\text { 11. How much would you say that this provider cares about you as a } \\
\text { person? }\end{array}$ & 370 & 1.24 & 0.47 & $\begin{array}{l}1-\text { Very much } \\
2-\text { A fair amount } \\
3 \text { - A little } \\
4-\text { Not at all } \\
\end{array}$ & $\begin{array}{l}0.784 \\
0.200 \\
0.014 \\
0.003 \\
\end{array}$ \\
\hline 12. To what extent does your provider know about your family life? & 369 & 1.78 & 0.86 & $\begin{array}{l}1 \text { - Completely } \\
2-\text { Mostly } \\
3-\text { A little } \\
4-\text { Not at all }\end{array}$ & $\begin{array}{l}0.447 \\
0.379 \\
0.119 \\
0.054\end{array}$ \\
\hline $\begin{array}{l}\text { 13. How comfortable are you discussing personal problems related } \\
\text { to your health with your provider? }\end{array}$ & 371 & 1.27 & 0.54 & $\begin{array}{l}1 \text { - Completely } \\
2-\text { Mostly } \\
3 \text { - A little } \\
4-\text { Not at all }\end{array}$ & $\begin{array}{l}0.768 \\
0.199 \\
0.024 \\
0.008 \\
\end{array}$ \\
\hline $\begin{array}{l}\text { 14. To what extent does your provider respect beliefs, values and } \\
\text { customs? }\end{array}$ & 352 & 1.28 & 0.54 & $\begin{array}{l}1 \text { - Completely } \\
2 \text { - Mostly } \\
3 \text { - A little } \\
4 \text { - Not at all } \\
\end{array}$ & $\begin{array}{l}0.759 \\
0.213 \\
0.020 \\
0.009 \\
\end{array}$ \\
\hline $\begin{array}{l}\text { 15. To what extent does your provider consider your thoughts and } \\
\text { feelings? }\end{array}$ & 368 & 1.29 & 0.52 & $\begin{array}{l}\text { - Completely } \\
2 \text { - Mostly } \\
3 \text { - A little } \\
4 \text { - Not at all } \\
\end{array}$ & $\begin{array}{l}0.742 \\
0.236 \\
0.016 \\
0.005 \\
\end{array}$ \\
\hline 16. To what extent does your provider show you compassion? & 368 & 1.24 & 0.47 & $\begin{array}{l}\text { - Completely } \\
2 \text { - Mostly } \\
3 \text { - A little } \\
4 \text { - Not at all } \\
\end{array}$ & $\begin{array}{l}0.785 \\
0.193 \\
0.022 \\
0.000 \\
\end{array}$ \\
\hline 17. To what extent does your provider really listen to you? & 373 & 1.21 & 0.45 & $\begin{array}{l}1 \text { - Completely } \\
2 \text { - Mostly } \\
3 \text { - A little } \\
4 \text { - Not at all } \\
\end{array}$ & $\begin{array}{l}0.807 \\
0.177 \\
0.016 \\
0.000 \\
\end{array}$ \\
\hline 18. To what extent do you trust your provider? & 372 & 1.22 & 0.47 & $\begin{array}{l}1 \text { - Completely } \\
2 \text { - Mostly } \\
3 \text { - A little } \\
4 \text { - Not at all } \\
\end{array}$ & $\begin{array}{l}0.809 \\
0.167 \\
0.024 \\
0.000 \\
\end{array}$ \\
\hline \multicolumn{6}{|l|}{ Factor 3: Roles ( $\alpha=0.809)$} \\
\hline $\begin{array}{l}\text { 9. To what extent did you and your provider discuss your respective } \\
\text { roles? }\end{array}$ & 340 & 1.71 & 1.00 & $\begin{array}{l}1 \text { - Completely } \\
2 \text { - Mostly } \\
3 \text { - A little } \\
4 \text { - Not at all } \\
\end{array}$ & $\begin{array}{l}0.582 \\
0.238 \\
0.071 \\
0.109 \\
\end{array}$ \\
\hline $\begin{array}{l}\text { 10. To what extent did your provider encourage you to take the role } \\
\text { you wanted in your own care? }\end{array}$ & 348 & 1.53 & 0.88 & $\begin{array}{l}1 \text { - Completely } \\
2 \text { - Mostly } \\
3 \text { - A little } \\
4 \text { - Not at all }\end{array}$ & $\begin{array}{l}0.664 \\
0.218 \\
0.046 \\
0.072\end{array}$ \\
\hline
\end{tabular}

PPPC-R, revised Patient Perception of Patient-Centeredness questionnaire; SD, standard deviation. 


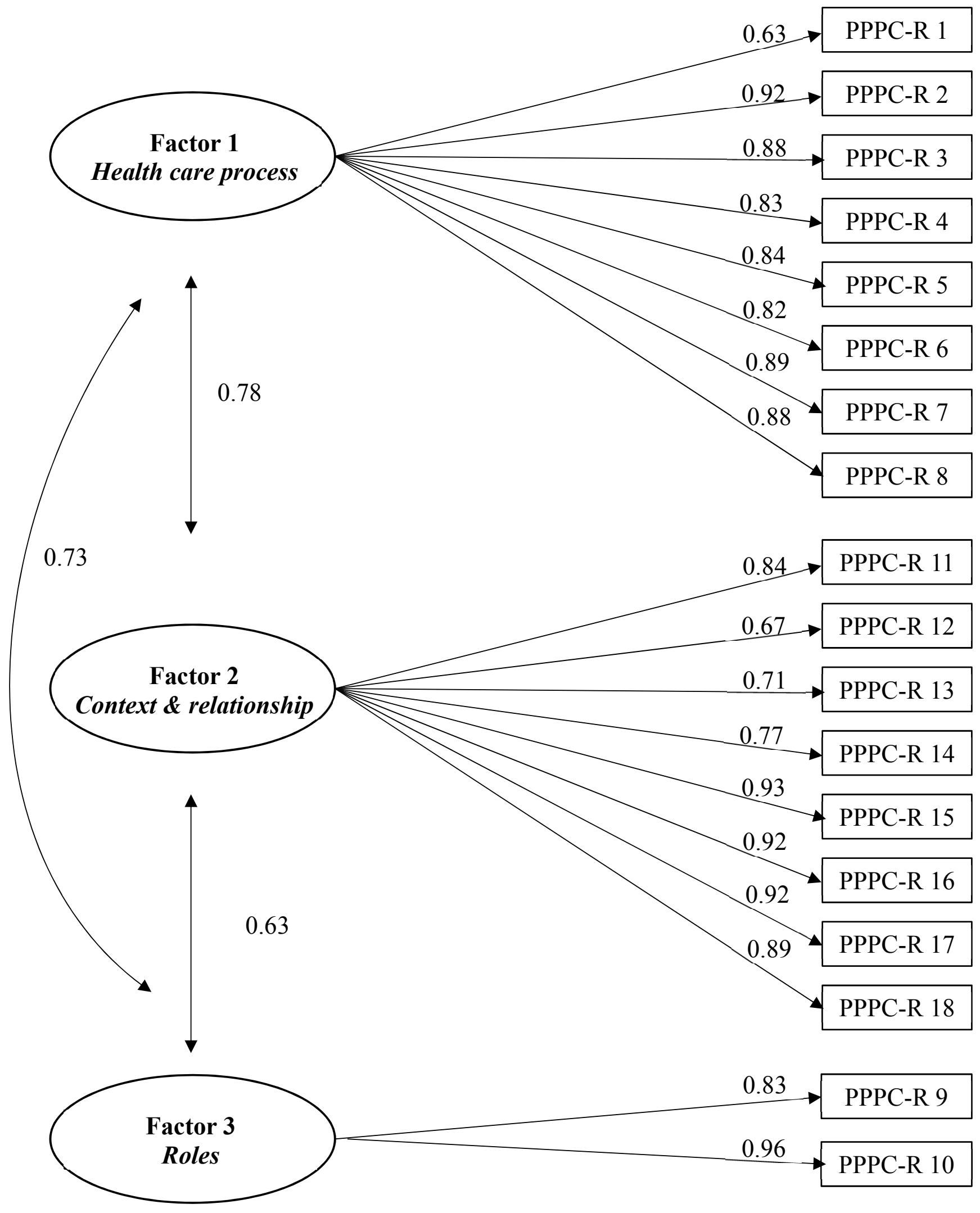

Figure 2. Confirmatory factor analysis of 3-factor structure for the 18-item revised Patient Perception of PatientCenteredness (PPPC-R) questionnaire. (All parameter estimates [loadings and correlations] are standardized and statistically significant.) 
Table 3. Number of PPPC-R Items Loading on to Each Factor by the Components of the PCCM Conceptual Framework

\begin{tabular}{|c|c|c|c|}
\hline PCCM Conceptual Framework & $\begin{array}{c}\text { F1: Health Care } \\
\text { Process (PCCM } \\
\text { Components } 1 \& 3 \text { ) }\end{array}$ & $\begin{array}{c}\text { F2: Context \& } \\
\text { Relationship (PCCM } \\
\text { Components } 2 \& 4 \text { ) }\end{array}$ & $\begin{array}{l}\text { F3: Roles (PCCM } \\
\text { Component 3) }\end{array}$ \\
\hline $\begin{array}{l}\text { Component 1: Exploring health, disease, and } \\
\text { illness experience }\end{array}$ & 2 items & 1 item & \\
\hline Component 2: Understanding whole person & & 4 items & \\
\hline Component 3: Finding common ground & 6 items & & 2 items \\
\hline Component 4: Enhancing relationship & & 3 items & \\
\hline Total number of items in factor & 8 items & 8 items & 2 items \\
\hline
\end{tabular}

PCCM, patient-centered clinical method. PPPC-R, revised Patient Perception of Patient-Centeredness questionnaire.

Do you care about me? Can I trust you? We make the distinction in the PCCM that, in Component 2, the clinician elicits issues regarding the patient's proximal and distal contexts that are pertinent to a particular encounter, in contrast to Component 4, which involves enhancing the relationship over time and multiple encounters. Given that these two components concern the person not just as a patient but as a whole person, it is not surprising that the patient experiences these items as part of one construct. The 1 item that we hypothesized would be part of the Component 1 construct, but instead loaded onto F2 (which encompassed Components 2 and 4), concerned the extent to which a patient's clinician considers the patient's thoughts and feelings. We considered this to be part of Component 1 in which the clinician explores the patient's thoughts and feelings about the illness experience in particular and, more broadly, the reason for the encounter. However, we realized that this was a misclassification on our part because the patient interprets this more generally (as it is worded) to be about their overall thoughts and feelings, not limited to their illness. Therefore, F2 generally combines PCCM Components 2 and 4 into a factor about context \& relationship.

Factor 3 was composed of 2 items that were hypothesized to be part of Component 3 (finding common ground) that did not load on either of the other two factors. These 2 items concern the roles that the patient and the clinician will play in the patient's care. Our experience in using the PPPC has been that these 2 questions can cause confusion for some patients. Patients may have trouble understanding what we mean by taking a role in their own care, suggesting that discussing their role is still rather a rare occurrence for patients. This may be especially true for a general primary care patient sample, such as was the case in this study, because visits may have been for more straightforward reasons that made examining roles not as important to these patients. Therefore, it was not entirely surprising that these 2 items were a discrete factor in the statistical analysis. We have decided to retain these 2 items because they are an important part of patient-centered care; however, they need to be interpreted with caution because they may not be clear to patients, and statistically we prefer that a factor have at least 4 items to be stable.

The validity of the PPPC-R is supported by some congruence between the conceptual framework (the PCCM) and the statistical analysis. The content of the items included in the 3-factor model appear to overlap with the content suggested by the conceptual aspects of the 4 PCCM components, but there was not 1:1 correspondence. The 4 components of the 
PCCM represent conceptually what is important when teaching, researching, and providing patientcentered care. The PPPC-R represents the PCCM as it is experienced by the patient. This means that when using the PCCM and weaving together the 4 components, patients may receive care that they characterize in primarily two distinct ways: how the provider attends to the actual health care process; and how the provider attends to the context \& relationship.

Future research will be conducted to determine if the factor structure of the PPPC-R cross-validates in different patient populations, different countries, and for different types of clinicians. It will be important to test the factorial invariance of the PPPC-R (ie, number of factors and properties of the items) across nations that use this instrument. Future research also will examine whether the 2 items concerning roles constitute a separate factor requiring additional items and/or whether this same factor is identified in other patient populations.

The PPPC-R contains all but 3 of the original 14 PPPC items. We intend to include these 3 original items along with the PPPC-R in data collections performed in the near future. In this way, we can calculate the original PPPC scores until there is sufficient evidence of the robustness of the new PPPC-R measure. Additionally, we recommend that those using the PPPC-R calculate a mean overall score based on all 18 items. While subscale scores can be calculated, caution is suggested until further validation of the measure is undertaken.

\section{CONCLUSIONS}

This paper describes the factor structure of the revised Patient Perception of Patient-Centeredness (PPPC-R) questionnaire. The strength of this measure is its basis in clinical practice, employing the patient-centered clinical method ${ }^{8}$ as its conceptual framework. This new 18-item PPPC-R measures the aspect of patientcenteredness that concerns the patient-clinician relationship, that is, the degree to which patients find health care encounters to be patient-centered. With increasing recognition of the importance of patient-oriented outcomes, the PPPC-R provides an assessment of patient-centeredness from the most important perspective, that of the patient.

\section{Patient-Friendly Recap}

- It is important to accurately obtain the viewpoint of the patient when determining "how patient-centered" a health care encounter truly was.

- The authors revisited their previously validated questionnaire measuring patient-centeredness in an effort to update and align it with the latest framework for providing patient-centered care.

- After analysis of existing and proposed questions, a revised 18-item survey replaced the previous 14 -item version. Health providers can use patient-centered survey results to measure and improve their practices.

\section{Author Contributions}

Study design: Ryan, Brown, Stewart. Data acquisition or analysis: Ryan, Brown, Tremblay. Manuscript drafting: Ryan, Brown. Critical revision: all authors.

\section{Conflicts of Interest}

None.

\section{Funding Sources}

The authors acknowledge the support of the Ontario Ministry of Health and Long-Term Care (Toronto, Canada) and the Ontario College of Family Physicians (Toronto, Canada). The views expressed are those of the authors and do not necessarily reflect those of either organization. Dr Ryan was funded by the Canadian Institutes for Health Research community-based primary health care innovation team Patient-Centred Innovations for Persons With Multimorbidity (2014-2018). Dr Stewart was funded by the Dr Brian W. Gilbert Canada Research Chair in Primary Health Care Research (2003-2017).

\section{References}

1. Mead N, Bower P. Patient-centredness: a conceptual framework and review of the empirical literature. Soc Sci Med. 2000;51:1087-110. CrossRef

2. Epstein RM, Street RL Jr. Patient-Centered Communication in Cancer Care: Promoting Healing and Reducing Suffering. NIH Publication No. 07-6225. Bethesda, MD: National Cancer Institute, 2007.

3. Law S, Flood C, Gagnon D; on behalf of the Listening for Direction II partners. Listening for Direction III: National Consultation on Health Services and Policy Issues, 20072010. Ottawa, Canada: Canadian Health Services Research Foundation, 2008.

4. Ontario Ministry of Health and Long-Term Care. ExternallyInformed Annual Health Systems Trends Report - Second Edition. Toronto, Canada: Health System Planning and Research Branch, 2009. 
5. Härter M, van der Weijden T, Elwyn G. Policy and practice developments in the implementation of shared decision making: an international perspective. Z Evid Fortbild Qual Gesundhwes. 2011;105:229-33. CrossRef

6. National Health Services Department of Health. Liberating the NHS: no decision about me, without me. Government response. Published 2012 Dec 13. https://www.gov.uk/government/uploads/ system/uploads/attachment_data/file/216980/Liberating-theNHS-No-decision-about-me-without-me-Government-response. pdf. Accessed January 14, 2019.

7. Little P, Everitt H, Williamson I, et al. Preferences of patients for patient centred approach to consultation in primary care: observational study. BMJ. 2001;322:468-72. CrossRef

8. Stewart M, Brown JB, Boon H, Galajda J, Meredith L, Sangster M. Evidence on patient-doctor communication. Cancer Prev Control. 1999;3:25-30.

9. Krupat E, Rosenkranz SL, Yeager CM, Barnard K, Putnam SM, Inui TS. The practice orientations of physicians and patients: the effect of doctor-patient congruence on satisfaction. Patient Educ Couns. 2000;39:49-59. CrossRef

10. Fossum B, Arborelius E. Patient-centred communication: videotaped consultations. Patient Educ Couns. 2004;54:163-9. CrossRef

11. Golin CE, DiMatteo MR, Gelberg L. The role of patient participation in the doctor visit. Implications for adherence to diabetes care. Diabetes Care. 1996;19:1153-64. CrossRef

12. Stevenson, FA, Cox K, Britten N, Dundar Y. A systematic review of the research on communication between patients and health care professionals about medicines: the consequences for concordance. Health Expect. 2004;7:235-45. CrossRef

13. Zolnierek, KB, Dimatteo MR. Physician communication and patient adherence to treatment: a meta-analysis. Med Care. 2009;47:826-34. CrossRef

14. Stewart M, Brown JB, Donner A, et al. The impact of patientcentered care on outcomes. J Fam Pract. 2000;49:796-804.

15. Stewart M, Brown JB, Hammerton J, et al. Improving communication between doctors and breast cancer patients. Ann Fam Med. 2007;5:387-94. CrossRef

16. Greenfield S, Kaplan SH, Ware JE Jr, Yano EM, Frank HJ. Patients' participation in medical care: effects on blood sugar control and quality of life in diabetes. J Gen Intern Med. 1988;3:448-57. CrossRef

17. Kaplan SH, Greenfield S, Ware JE Jr. Assessing the effects of physician-patient interactions on the outcomes of chronic disease. Med Care. 1989;27(3 Suppl):S110-27. CrossRef

18. Griffin SJ, Kinmonth AL, Veltman MW, Gillard S, Grant J, Stewart M. Effect on health-related outcomes of interventions to alter the interaction between patients and practitioners: a systematic review of trials. Ann Fam Med. 2004;2:595-608. CrossRef

19. Rao JK, Anderson LA, Inui TS, Frankel RM. Communication interventions make a difference in conversations between physicians and patients: a systematic review of the evidence. Med Care. 2007;45:340-9. CrossRef
20. Epstein RM, Franks P, Shields CG, et al. Patient-centered communication and diagnostic testing. Ann Fam Med. 2005;3:415-21. CrossRef

21. Stewart M., Ryan BL, Bodea C. Is patient-centred care associated with lower diagnostic costs? Healthc Policy. 2011;6(4):27-31.

22. Jani B, Bikker AP, Higgins M, et al. Patient centredness and the outcome of primary care consultations with patients with depression in areas of high and low socioeconomic deprivation. Br J Gen Pract. 2012;62:e576-81. CrossRef

23. Stewart M, Brown JB, Weston WW, McWhinney IR, McWilliam CL, Freeman TR. Patient-Centered Medicine: Transforming the Clinical Method, Second Edition. Thousand Oaks, CA: SAGE Publications, 1995.

24. Stewart M, Brown JB, Weston WW, McWhinney IR, McWilliam CL, Freeman TR. Patient-Centered Medicine: Transforming the Clinical Method, Third Edition. London, United Kingdom: Radcliffe Publishing, 2014.

25. Reinders ME, Blankenstein AH, Knol DL, de Vet HC, Van Marwijk HW. Validity aspects of the patient feedback questionnaire on consultation skills (PFC), a promising learning instrument in medical education. Patient Educ Couns. 2009;76:202-6. CrossRef

26. Clayton MF, Dudley WN, Musters A. Communication with breast cancer survivors. Health Commun. 2008;23:207-21. CrossRef

27. Clayton MF, Dudley WN. Patient-centered communication during oncology follow-up visits for breast cancer survivors: content and temporal structure. Oncol Nurs Forum. 2009;36(2):E68-79. CrossRef

28. Ishikawa H, Hashimoto H, Roter DL, Yamazaki Y, Takayama T, Yano E. Patient contribution to the medical dialogue and perceived patient-centeredness. An observational study in Japanese geriatric consultations. J Gen Intern Med. 2005;20:906-10. CrossRef

29. Fiscella K, Franks P, Srinivasan M, Kravitz RL, Epstein R. Ratings of physician communication by real and standardized patients. Ann Fam Med. 2007;5:151-8. CrossRef

30. Muthén LK, Muthén BO. Mplus User's Guide, Sixth Edition. Los Angeles, CA: Muthén \& Muthén, 1998-2010.

31. Baker FB, Kim SH (eds). Item Response Theory: Parameter Estimation Techniques, Second Edition. New York, NY: Marcel Dekker, 2004.

32. Samejima F. Estimation of latent ability using a response pattern of graded scores. Psychometrika. 1969;34(Suppl 1):1-97. CrossRef

33. Ryan BL, Brown JB, Glazier RH, Hutchison B. Examining primary healthcare performance through a triple aim lens. Healthc Policy. 2016;11(3):19-31. CrossRef

34. Fornell C, Larcker DF. Evaluating structural equation models with unobservable variables and measurement error. $J$ Mark Res. 1981;18:39-50. CrossRef

(C) 2019 Aurora Health Care, Inc. 